•综述・

\title{
转Bt基因抗虫作物对非靶标害虫的影响
}

\author{
关正君 ${ }^{1}$ 鲁顺保 ${ }^{2}$ 霍艳林 ${ }^{3}$ 郝浩永 ${ }^{3}$ 曹建斌 魏 伟 $4^{*}$ 刘 标 $5^{*}$ \\ 1 (运城学院生命科学系, 山西运城 044000) \\ 2 (江西师范大学生命科学学院, 南昌 330022) \\ 3 (运城学院理科实验中心, 山西运城 044000) \\ 4 (中国科学院植物研究所植被与环境变化国家重点实验室, 北京 100093) \\ 5 (环境保护部南京环境科学研究所, 南京 210042)
}

摘要: 转基因作物的长期大面积种植, 在为农业生产带来惠益的同时, 对农业生态系统的健康和稳定可能会产生 潜在的影响。转基因作物表达的Bt蛋白对靶标害虫起到较好的控制效果, 而对Bt蛋白不敏感的非靶标害虫种群可 能会迅速发展起来, 对作物造成为害。随着抗虫转基因作物的连续多年种植, 科学家们对于田间杀虫剂施用量的 增减看法不尽一致。通过总结已有的研究报道, 本文以Bt玉米和Bt棉花为例, 分析了大田中非靶标害虫暴发的现 状, 以及暴发的主要原因(如杀虫剂的使用、害虫天敌减少和物种替代)。在生产实践中, 抗虫作物的长期大面积释 放导致广谱杀虫剂施用量减少, 田间非靶标害虫数量上升。因此今后需要继续开展更多的研究来综合评估种植转 $B t$ 基因作物产生的长期潜在影响, 优化害虫防治措施, 避免非靶标害虫暴发。

关键词: 抗虫; $\mathrm{Bt}$ 作物; 非靶标害虫; 暴发; 风险评价

\section{Effects of Bt crops on non-target insect pests}

\author{
Zhengjun Guan ${ }^{1}$, Shunbao $\mathrm{Lu}^{2}$, Yanlin $\mathrm{Huo}^{3}$, Haoyong $\mathrm{Hao}^{3}$, Jianbin $\mathrm{Cao}^{1}$, Wei Wei ${ }^{4 *}$, Biao $\mathrm{Liu}^{5^{*}}$ \\ 1 Department of Biological Sciences, Yuncheng University, Yuncheng, Shanxi 044000 \\ 2 College of Biosciences, Jiangxi Normal University, Nanchang 330022 \\ 3 Science Experimental Center, Yuncheng University, Yuncheng, Shanxi 044000 \\ 4 State Key Laboratory of Vegetation and Environmental Change, Institute of Botany, Chinese Academy of Sciences, Bei- \\ jing 100093 \\ 5 Nanjing Institute of Environmental Sciences of the Ministry of Environmental Protection, Nanjing 210042
}

\begin{abstract}
The long-term large-scale planting of genetically modified (GM) crops may have potential impacts on the health and stability of agricultural ecosystems while benefitting agricultural production. Bt proteins expressed in Bt crops have a good control on target pests. However, non-target insects that are not susceptible to Bt toxins may have increased populations rapidly, causing significant damage to crops. With the long-term continued cultivation of insect-resistant GM crops, different reports and views on the amounts of pesticide applications have been reported. Based on existing research, we reviewed the characteristics and status of non-target insect pest outbreaks and analyzed the main causes of the outbreaks (such as insecticide use, decrease of natural enemies, and species replacement). In addition, we discussed the effects of GM crops on non-target pests over long-term cultivation using Bt corn and cotton as examples. Given the existing problems of non-target insect outbreaks due to commercial applications of Bt crops, further studies on monitoring the efficacies of insect-resistant GM crops are necessary to prevent outbreaks of non-target pests needed for sustainable agriculture.
\end{abstract}

Key words: insect-resistanceBt crops; non-target pests; outbreak; risk assessment

农药的使用已有悠久的历史，因其应用范围 广、见效快等特点，被人们大量生产和使用。然而， 
大多数杀虫剂毒性高、化学性质稳定, 长期大量使 用会造成农药残留、环境污染、害虫抗性增加, 甚 至导致害虫的再猖獗(曾任森等, 2016)。随着现代生 物技术的不断发展, DNA重组技术使转基因抗虫作 物得以应用和推广, 因此逐渐减少了由农药使用带 来的许多不利影响。最为典型的例子是来自于土壤 细菌苏云金芽孢杆菌(Bacillus thuringiensis, Bt) 的 Cry晶体毒蛋白在转 $B t$ 基因作物(简称 $\mathrm{Bt}$ 作物)中的 表达。转 $B t$ 基因作物的种植有效地减少了广谱化学 农药的使用, 提高了农产品的产量和质量, 具备解 决粮食短缺和能源贵乏等问题的潜力(Brookes \& Barfoot, 2016)。

转Bt基因作物自1996年被批准商业化种植以来, 其抗虫效果显著, 特异性好(Carrière et al, 2010; Ricroch et al, 2014)。转Bt 基因作物表达的Bt蛋白对 靶标害虫可以起到较好的杀虫效果, 从目前报道来 看, 推广种植转 $B t$ 基因作物可以减少人们对传统杀 虫剂的过度依赖, 进而能够保护一些经济昆虫(如 家虫)种群的丰富度(Lu et al, 2012; Areal et al, 2013; 傅强等, 2013; 杨艳等, 2014)。人们通常认为Bt毒素 可能会对非靶标生物有害, 但远低于广谱杀虫剂带 来的为害(Areal \& Riesgo, 2015)。尽管如此, Bt作物 长期大规模的环境释放, 会导致靶标昆虫抗药性的 产生与进化, 同时, 对毒蛋白不敏感的其他非靶标 昆虫可能会代替靶标害虫, 在田间成为主要的害虫 (刘标, 2016; Arpaia et al, 2017)。这些为害一旦发生, 也将会影响食物链上的其他生物(魏伟等, 2016), 最 终将可能会对农业发展与经济效益带来负面影响。 因此, 本文通过总结已有的研究报道, 分析了 Bt作 物种植过程中非靶标害虫暴发的主要影响, 探明引 起害虫暴发的主要原因, 并为未来防治非靶标害虫 的暴发提供建议。

\section{2 转Bt基因抗虫作物及非靶标生物}

转 $B t$ 基因抗虫作物是基因转化技术较为成功, 且在全世界范围广泛种植的一类转基因作物。Bt棉 花(Gossypium hirsutum)和Bt玉米(Zea mays)是转基 因技术控制害虫应用最广泛的农作物，此外，Bt基 因还应用于茄子、大豆和杨树等作物。2016年，全 球转 $B t$ 基因作物种植2,310万公顷, 比2015年稍有下 降, 但Bt抗虫和除草剂抗性复合性状的转基因作物 却从 2015 年的 5,850 万公顷上升到2016年的 7,540 万
公顷(ISAAA, 2016)。

对于 Bt作物而言, 伴随着对靶标害虫的控制, 被抑制的害虫可能对转基因作物产生的 $\mathrm{Bt}$ 杀虫蛋 白产生抗性, 靶标害虫种群数量再次快速上升, 出 现害虫再猖獗(pest resurgence)的现象, 对作物造成 严重为害(林珠凤等, 2015; 魏伟和马克平, 2016)。 一般来说, Bt作物的靶标生物种类相对较少，例如， 含有 Cry3 蛋白的 $\mathrm{Bt}$ 玉米仅可以抗玉米根叶甲属 (Diabrotica)的几个种, 表达Cry1和Cry2蛋白的Bt玉 米和 Bt 棉花主要对鳞翅目昆虫如棉铃虫 (Helicoverpa armigera)、玉米蛽(Ostrinia nubilalis)有效。研 究表明，在美国，美洲棉铃虫(Helicoverpa zea)的田 间种群对转 $B t$ 基因棉花已产生了抗性(Gassmann et $\mathrm{al}$, 2009)。另外由于转基因作物的种植，使得田间化 学杀虫剂施用量减少，同时降低了田间昆虫天敌的 数量, 导致其他非靶标害虫快速增加, 有可能成为 田间主要的害虫(阇亮珍等, 2011; Catarino et al, 2015)。非巴 标生物可能直接或间接地与转基因作物 接触，或者存在于转基因作物产品中，随后可能被 释放到农业生态系统或邻近的栖息地(Arpaia, 2010; Naranjo, 2014)。当Bt毒蛋白与非靶标生物直接接触, 或者通过间接方式导致非靶标生物所依赖的生态 系统发生改变时, Bt作物可能会对这种非靶标生物 产生致死或亚致死的作用(Snow et al, 2005)。

$\mathrm{Bt}$ 作物的非靶标生物种类十分广泛(叶恭银等, 2011), 一方面Bt作物可能直接对Bt蛋白不敏感的其 他节肢动物害虫产生影响, 如棉蚜 (Aphis gossypii )、盲蝽蟓、蝴蝶等(Hagenbucher et al, 2013; Han et al, 2013; Kumar et al, 2014; Ladics et al, 2015); 另 一方面可能影响自然生态系统的服务功能, 如生物 防治(如天敌对害虫的控制功能)、传粉功能(如Bt作 物对蜜蜂(Apis mellifera)等的影响)和废弃物分解 (Campos \& Hernandez, 2015; Luttrell et al, 2015; Shahid et al, 2016; Zeilinger et al, 2016)。例如，刺吸 性害虫盲蝽主要出现在中国、美国和澳大利亚的Bt 棉田中。在中国Bt棉主产区, 盲蝽不仅在棉田中感 染严重，而且也会为害同一地区种植的其他作物 (Lu et al, 2008, 2010)。在美国中南部和东南部的部 分地区, 美洲蝽(Euschistus servus)和稻绿蝽(Nezara viridula)同时暴发, 成为棉田的主要害虫(Zeilinger et al, 2016)。此外, Bt作物可能对一些小型哺乳动物 
(如大鼠)、土壤无脊椎动物、土壤微生物产生潜在 影响(Kilic \& Akay, 2008; 袁一杨和戈峰, 2010; Guan et al, 2016)。到目前为止, 科学家仅对数量有 限的非靶标物种进行了研究。只有充分了解某个特 定的农业生态系统中普遍存在的节肢动物类群, 才 能更为全面和准确地评价不同营养水平上Bt作物 对非靶标生物的影响(Meissle et al, 2010; Catarino et al, 2015)。

\section{Bt作物农田中非靶标害虫暴发的诱因}

$\mathrm{Bt}$ 作物的广泛种植可能会对农业生态系统的 功能和农业的经济效益产生潜在影响(Catarino et al, 2015)。随着 Bt作物的长期大田种植, 非靶标害 虫种群可能会在适宜的条件下逐渐发展成为田间 的主要害虫(Lu et al, 2010; Catarino et al, 2015), 并 导致非靶标害虫的大暴发。

\section{1 化学杀虫剂使用的变化}

$\mathrm{Bt}$ 作物表达的毒蛋白可以减轻化学杀虫剂带 来的负面影响(Meissle et al, 2010; 王园园等, 2011; Krishna \& Qaim, 2012)。但是, 在一些地区如中国和 美国, Bt棉田中非靶标害虫暴发的现象似乎与广谱 化学杀虫剂使用的普遍减少密切相关(Naranjo et al, 2008; Lu et al, 2010)。化学 杀虫剂的施用可以同时防 治一些非靶标害虫(如盲蝽、叶蝉、蓟马)(Catarino et al, 2015), 但也会对一些天敌造成伤害。田间天敌数 量的降低, 可能导致其他非靶标害虫如红蜘蛛 (Tetranychus cinnbarinus)、蚜虫和粉虫的暴发(陆宴 辉, 2012)。印度的Bt棉田也存在由粉蚜、蓟马和叶 蝉引起的类似问题(Naranjo, 2014)。同样, 有研究报 道了 $\mathrm{Bt}$ 玉米种植田中几种非靶标害虫种群数量大 幅度增长的现象(Eizaguirre et al, 2010; Pérez-Hedo et al, 2012)。由于Bt作物的种植未能完全控制各种 害虫的为害, 因此, 在某些情况下, 农民不得不重 新开始使用杀虫剂。随着转基因抗虫作物的连续多 年种植, 杀虫剂的用量正在逐渐增加 (Benbrook, 2012)。控制靶标害虫的杀虫剂用量可能逐渐减少, 但控制非靶标害虫的杀虫剂用量可能会增加, 因此, $\mathrm{Bt}$ 棉田中特异性杀虫剂的使用以及化学防治与生 物防治之间的协调将是今后研究工作的重点 (National Academies of Sciences, Engineering, and Medicine, 2016)。

\section{2 害虫天敌减少}

$\mathrm{Bt}$ 作物产生的毒素可以通过直接或间接的方 式对天敌产生影响(马惠等, 2009; Yang et al, 2017)。 首先，杀虫蛋白的摄入会对天敌直接产生影响 (Stephens et al, 2012)。转Bt基因作物农田天敌主要 包括两大类：捕食性天敌和寄生性天敌。综合已有 研究报道, 在商业化种植的转 $B t$ 基因棉田中, 随着 寄生靶标害虫的减少，其寄生性天敌数量也呈现明 显减少的趋势(间亮珍等, 2011)。其次, Bt毒素可能 会对捕食者(食肉动物)产生类似于靶标害虫的不利 影响(Andow et al, 2006)。研究表明, Bt蛋白可以通 过猎物如玉米蚜(Rhopalosiphum maidis)和禾谷缢管 蚜(Rhopalosiphum padi)从Cry3Bb Bt玉米植株传递 给捕食者(异色㼼虫(Harmonia axyridis)), 从而使猎 物的寿命显著缩短(Stephens et al, 2012)。此外，毒 素会通过食物链在生物体内积累, 进而驱动生态系 统内的级联效应(Wei et al, 2008; Chen et al, 2009)。 $\mathrm{Bt}$ 毒素的间接影响通过减少猎物群体数量或者降 低猎物的营养品质等方式来体现。例如，在转 $B t$ 基 因棉田中，靶标生物的高死亡率导致特异性天敌的 减少(闵亮珍等, 2011)。同时，存活的猎物也可能因 摄取Bt蛋白后营养状况下降，对天敌的表型、发育 甚至存活均产生很大的影响(Stephens et al, 2012)。 此外, 靶标生物可能会迁移到非Bt作物的农田去寻 找更好的食物资源(Naranjo，2005)，导致Bt作物田 中非靶标害虫的捕食者的猎物资源不足，进而也会 主动迁移到相邻的传统作物农田, 从而降低了Bt作 物农田里捕食者(即天敌)的丰富度(Razze \& Mason, 2012), 最终使得该作物农田或者邻近作物农田中 非靶标害虫数量和丰富度增加(Gross \& Rosenheim, 2011)。毫无疑问，这些昆虫天敌在靶标和非靶标害 虫生物防治中发挥着重要作用(Naranjo, 2010), 天 敌数量的减少可能在一定程度上降低了对靶标和 非靶标害虫种群的控制。

\section{3 生态位变化及物种替代}

生态系统是一个平衡的整体, 每个物种都占据 一定的生态位空间，抗虫转基因作物的引入以及物 种竞争可能会引起物种替代和生态位变化(魏伟等, 2016)。Bt作物的大面积应用开辟了作物大田鳞翅目 害虫治理的新途径，靶标害虫的有效控制使杀虫剂 在 $\mathrm{Bt}$ 作物农田中的使用模式发生了改变, 从而导致 多种害虫的种群地位和生态位空间出现了演替变 
化(陆宴辉, 2012)。目前, 国内外对Bt棉花种植带来 的害虫种群地位演替问题认识还不全面, 靶标害虫 和非靶标害虫之间的物种替代常常被忽视(陆宴辉 和梁革梅, 2016)。研究表明, 当Bt毒素蛋白成功控 制某一种靶标害虫之后, 其他不敏感害虫将会利用 新的可用生态资源(Gross \& Rosenheim, 2011; Catarino et al, 2015)。例如, 在20世纪90年代中期, 随 着转基因玉米的推广种植, 靶标害虫玉米蛽和美洲 棉铃虫减少，与此同时, $\mathrm{Bt} 玉$ 米的推广导致田间管 理发生改变(如保护性耕作、减少杀虫剂的使用), 使 一种原产于美国西部和中部的西方豆夜蛾(Striacosta albicosta)的生态位逐渐扩大(Dorhout \& Rice, 2010; Hutchison et al, 2011)。在美国和加拿大种植玉 米的某些地区, 该害虫已经逐渐变成当地主要害虫 (Lindroth et al, 2012), 为害表达Cry1Ab和Cry9C毒 蛋白的转基因作物(Dorhout \& Rice, 2010)在美国, 靶标害虫棉铃虫和烟芽夜蛾(Heliothis virescens)的 有效控制导致Bt棉田一些非靶标害虫(如稻绿蝽和 美洲蝽)的种群增长(Zeilinger et al, 2016)。在澳大利 亚, Bt棉种植使棉铃虫和澳洲棉铃虫得到了有效控 制, 但绿盲蝽(Apolygus lucor $\mu m$ )、稻绿蝽、叶蝉、 蓟马等害虫的发生不断加重(Naranjo et al, 2008)。在 中国大多数棉区, 盲蝽成虫时期正好是二代棉铃虫 发生高峰期。由于Bt棉田的二代棉铃虫不需要进行 化学防治, 从而导致盲蝽数量不断上升, 种群暴发 成灾, 且波及其他寄主作物(Lu et al, 2010; 陆宴辉 和梁革梅, 2016)。随着 Bt作物种植的全球扩大化, 探明哪些物种对转基因毒素敏感是非常重要的, 这 将有助于进一步采取相应的防治措施, 避免这些物 种在同一转基因作物中竞争生态位资源, 不利于田间 害虫的管理，影响转基因抗虫作物的可持续利用。

\section{$4 \mathrm{Bt}$ 作物对非靶标害虫的影响及防}

下面主要以两种主要的转基因抗虫作物 $\mathrm{Bt}$ 棉 花和Bt玉米为例, 分析转基因作物在长期种植过程 中对非靶标害虫的影响及防控研究进展。

\subsection{Bt棉田非靶标害虫的影响及防控}

在美国中南部和东南部的一些棉花种植地区, Bt棉花推广之前, 农民每年在每公顷棉田里平均使 用17次杀虫剂; 种植Bt棉花之后, 用于防治靶标害 虫的杀虫剂使用减少到5次(Naranjo, 2010)。然而, 由于非靶标害虫(如蚜虫、叶蝉、盲蝽)的数量显著
增加, 用于防治这些害虫的杀虫剂剂量比原来增加 了近一倍。尽管如此, 美国转基因Bt棉田中的大部 分非靶标害虫，通过选择杀虫剂的合理使用和其他 综合管理策略，最终均得到了有效的控制(Naranjo \& Ellsworth, 2009)。此外，在澳大利亚，绿盲蝽成为 Bt棉田的主要非靶标害虫, 可以采用将紫花苜宿发 展为棉田绿盲蝽诱集植物、使用选择性杀虫剂、隐 蔽施药(如种子处理)等方法进行综合防治(Mccoll et al, 2011)。在印度, Bt棉田中扶桑绵粉蚧(Phenacoccus solenopsis)的发生与为害尤其严重。及时清 除田埂杂草能有效降低扶桑绵粉蚧的种群发生, 班 氏跳小蜂(Aenasius bambawalei)是控制这种害虫最 有效的天敌资源(Tanwar et al, 2011)。

在中国棉花种植地区，20世纪90年代早期，杀 虫剂的过度使用导致棉铃虫对大多数杀虫剂产生 耐药性(Wu \& Guo, 2005)。随着转基因Bt棉花的释 放，杀虫剂的施用量从每年大约 $61 \mathrm{~kg} / \mathrm{ha}$ 降低到 $12 \mathrm{~kg} / \mathrm{ha}$ (Huang et al, 2002)。在某些棉铃虫为害严 重的地区，Bt棉花的种植率接近于 $100 \%$ (Xu et al, 2008)。随后, 杀虫剂的使用量出现增长趋势, 主要 用来控制棉铃虫、盲蝽以及其他害虫(Pemsl et al, 2011)。在持续种植几年后, Bt作物最初的抗虫优势 逐渐减弱, 那些曾经被忽略的农业害虫逐渐变成了 农民的主要关注对象(Lu et al, 2010; Zhao et al, 2011)。例如, Bt棉花的种植较好地控制了靶标害虫 棉铃虫的为害, 同时也减轻了红铃虫(Pectinophora gassypiella)、玉米螟等害虫的为害(Lu et al, 2010)。 然而, 在华北地区大多数棉区，由于杀虫剂使用量 大幅度减少，一些常常被忽略的害虫为害加重，特 别是盲蝽的种群数量不断增加, 逐渐成为 $\mathrm{Bt}$ 棉田 的主要害虫( Lu et al, 2010)。此外，棉蚜、红蜘蛛、 斜纹夜蛾(Spodoptera litura)、扶桑绵粉蚧等害虫日 益成为Bt棉田新的威胁(陆宴辉, 2012)。

\subsection{Bt玉米田非靶标害虫的影响及防控}

过去的十多年里, 在美国中西部的玉米种植地 区, 转基因Bt玉米的种植广泛抑制了玉米螟(Ostrinia nubilalis)种群的为害(Hutchison et al, 2010)。然 而, 在美国Bt玉米田中，非靶标害虫西方豆夜蛾却 非常棘手，造成70\%的产量损失(Catangui \& Berg, 2006)。另外, 调查研究发现, 棉铃虫与草地贪夜蛾 (Spodoptera frugiperda) 是美国南部Bt玉米田中重要 的非靶标害虫, 严重影响玉米的产量和质量。这些 
害虫在表达Cry1 Ab 和Cry1F蛋白的Bt玉米大田中具 有一定的存活率(Hardke et al, 2011)。

在欧洲, 只允许种植由美国孟山都公司开发的 主要表达Cry1Ab蛋白的Bt玉米(MON810) (EFSA, 2010)。Cry1Ab蛋白对一些非靶标害虫(如西部玉米 根虫(Diabrotica virgifera)和粘虫(Mythimna unipuncta))并不具有高效抗性(Pérez-Hedo et al, 2012)。在 中欧和东欧国家, 这类害虫也越来越常见, 曾造成 意大利波河流域的玉米产量损失约3\% (Meissle et al, 2010)。研究表明, 粘虫对表达Cry1Ab蛋白的Bt 玉米仅表现轻度敏感(González-Cabrera et al, 2013), 转 $B t$ 基因玉米大田与非转基因亲本大田之间, 粘虫 的幼虫数量及其幼虫的发育均无显著性差异(PérezHedo et al, 2012)。随着针对靶标害虫的传统杀虫剂 应用的减少, 表达Cry1Ab蛋白的转基因玉米大面 积推广种植将可能导致粘虫的丰富度逐渐增加, 该 害虫可能会发展成为主要的害虫(González-Cabrera et al, 2013)。

总之, 在转基因 $\mathrm{Bt}$ 玉米和 $\mathrm{Bt}$ 棉花种植过程中, 非靶标害虫的显著增加与杀虫剂的使用有着必然 的联系(Dowd-Uribe, 2014)。一方面, 减少杀虫剂的 应用会导致对 $B t$ 作物表达的Bt蛋白不敏感的昆虫数 量增加(马惠等, 2009); 另一方面, 当非靶标害虫种 群突然暴发时, 喷酒广谱杀虫剂可能是最便宜和最 有效的解决方法。今后, Bt作物大面积种植对靶标 害虫抗性进化以及非靶标害虫影响的长期生态效 应以及综合防控, 将成为 $\mathrm{Bt}$ 棉花与 $\mathrm{Bt}$ 玉米生态安全 评价研究工作的重点(韩兰芝等, 2007; Gressel et al, 2016)。

\section{存在问题与展望}

目前已获得了大量的转基因作物生态风险评 估数据, 尤其是Bt作物对非靶标生物影响相关的田 间调查资料和实验室检测数据。这些证据大部分支 持 $\mathrm{Bt}$ 作物及其表达的杀虫晶体蛋白对非靶标生物 无直接的影响, 通过Bt作物推广的方法来控制靶标 害虫可能比传统杀虫剂的效果更好。然而, 像杀虫 剂一样, Bt作物改变了农业生态系统的过程和功 能。在某些情况下, Bt作物的种植减少了靶标害虫 的数量, 但它们的生态位可被其他非靶标害虫占据, 并且外源基因的导入, 有可能改变作物本身对非靶
标害虫的抗性化学成分的降低(Hagenbucher et al, 2013), 加上广谱性杀虫剂施用量的减少, 可能会导 致非靶标害虫的暴发。非靶标害虫暴发是众所周知 的现象, 但它们在转基因作物的研究与应用中通常 被忽视。

随着 $\mathrm{Bt}$ 作物的长期种植, $\mathrm{Bt}$ 作物通过直接或间 接的方式对非靶标害虫及害虫天敌产生潜在影响, 进而可能导致非靶标害虫成为田间主要的害虫, 控 制非靶标害虫的杀虫剂施用量随之会增加(陆宴辉, 2012)。通过抗虫蛋白来控制害虫的转基因作物的研 发与应用再次面临因杀虫剂大量使用而带来的挑 战(Pemsl et al, 2011)。已有的研究结果表明，非靶标 害虫将会对 Bt作物的经济和生态效益产生潜在影 响。即使是应用成功的Bt作物体系(如美国Bt棉花), 也需要通过化学防治(高效杀虫剂的笁选与选择杀 虫剂的使用)与生物防治相结合对非靶标害虫进行 综合治理(陆宴辉, 2012)。此外，当非靶标害虫遭受 杀虫剂的亚致死剂量时, 通常会产生毒物低剂量促 进效应，快速提高其繁殖率，导致非靶标害虫的暴 发(Guedes \& Cutler, 2014)。然而, 低剂量的Bt毒素 对非靶标害虫的促进效应机制尚不明确，需进一步 的研究。

现阶段已成功研发出可以同时表达多个Bt毒 蛋白的转基因作物新品种, 可以克服部分非靶标害 虫带来的为害。例如, 美国推广种植的转双基因 $(c r y 1 A c+c r y 2 A b)$ 的二代Bt棉花的杀虫谱有所扩大, 对甜菜夜蛾(Spodoptera exigua)、草地贪夜蛾的杀虫 活性明显增加(Tindall et al, 2009)。科学家们曾预期 这些具有复合性状的转基因作物将能减少由单一 性状的转基因作物引发的生态问题 (Shi et al, 2013)。从生态学的角度来看, 多种性状叠加的转基 因事件同样可能会加速生态系统的变化过程, 甚至 影响整个系统的快速响应和自我恢复能力。一些农 业生态系统的响应和恢复需要很长一段时间, 只有 通过长期研究才能有效地评估和监测所有的潜在 影响。当害虫持续接触 $\mathrm{Bt}$ 作物在各生长期产生的 $\mathrm{Bt}$ 毒素时，其物种和所在农田的食物链可能都会受到 影响, 并且随着时间的推移, 对Bt毒素敏感性较低 的害虫将会逐渐产生耐药性(Brévault et al, 2013)。 由于生态系统的变化过程存在着不确定性，一些实 验设计和研究过程考虑不全面, 忽略了生物、非生 物因素和环境因素的干扰，导致对转基因作物潜在 
影响的评估结论不尽一致(Kruger et al, 2012; DowdUribe, 2014; Catarino et al, 2015)。

一些研究工作者通过实验室模拟或可控制的 田间笼罩等手段, 开展了小规模的调查研究, 评估 了蛋白毒素对捕食者、猎物的影响或猎物对捕食者 产生的直接影响(Marvier et al, 2007; Wolfenbarger et al, 2008; Lövei et al, 2009)。但这些研究尚未考虑到 间接的时空效应对食物链各营养级物种种群动态 的影响(Andow et al, 2009)。在大田环境下, 作物害 虫的发生常常具有突发性、随机性、多样性和不均 匀性等特点, 还需要考虑相关的影响因素, 如农业 气候条件、农业生态环境、人为干预、新作物引入、 病虫害防治管理技术和其他难以界定的随机因素 (Catarino et al, 2015)。

$\mathrm{Bt}$ 作物对非靶标害虫及天敌的潜在影响可以 通过摄入的毒素直接产生或者通过农业生态系统 的变化而间接产生, 如害虫种群密度的变化 (Andow et al, 2006)。种群竞争也常常会导致生态机 会主义的产生(Dorhout \& Rice, 2010; Virla et al, 2010)。非靶标害虫的种群增长不太引人注意, 可能 需要数年时间才可能暴发并成为人们关注的重点。 因此, 今后还需要开展更多的研究来评估 $\mathrm{Bt}$ 作物的 长期潜在影响(Krishna \& Qaim, 2012)。

总之，尽管目前Bt作物应用趋势较好，但仍然 存在许多与农业生态系统变化相关的悬而未决的 问题。这些问题可能目前还不足以影响转基因技术 的使用, 但需要以审慎的态度开展进一步的研究工 作，为Bt作物大规模种植的田间害虫管理及可持续 利用方面提供切实可行的建议，同时也需要及时向 监管部门警示可能存在的问题和风险。

\section{参考文献}

Andow DA, Lövei GL, Arpaia S (2006) Ecological risk assessment for Bt crops. Nature Biotechnology, 24, 749-751.

Andow DA, Lövei GL, Arpaia S (2009) Cry toxins and proteinase inhibitors in transgenic plants do have non-zero effects on natural enemies in the laboratory: Rebuttal to Shelton et al. 2009. Environmental Entomology, 38, 1528-1532.

Areal FJ, Riesgo L (2015) Probability functions to build composite indicators: A methodology to measure environmental impacts of genetically modified crops. Ecological Indicators, 52, 498-516.

Areal FJ, Riesgo L, Rodriguez-Cerezo E (2013) Economic and agronomic impact of commercialized GM crops: A meta-analysis. Journal of Agricultural Science, 151, 7-33.
Arpaia S (2010) Genetically modified plants and non-target organisms: Analysing the functioning of the agro-ecosystem. Collection of Biosafety Reviews, 5, 12-80.

Arpaia S, Birch ANE, Kiss J, Loon JJAV, Messéan A (2017) Assessing environmental impacts of genetically modified plants on non-target organisms: The relevance of in planta studies. Science of the Total Environment, 583, 123-132.

Benbrook CM (2012) Impacts of genetically engineered crops on pesticide use in the U.S. - the first sixteen years. Environmental Sciences Europe, 24, 24.

Brévault T, Heuberger S, Zhang M, Ellers-Kirk C, Ni X, Masson L, Li X, Tabashnik BE, Carrière Y (2013) Potential shortfall of pyramided transgenic cotton for insect resistance management. Proceedings of the National Academy of Sciences, USA, 110, 5806-5811.

Brookes G, Barfoot P (2016) GM Crops: Global Socio-Economic and Environmental Impacts 1996-2014. PG Economics Ltd., UK.

Campos RC, Hernandez MIM (2015) Changes in the dynamics of functional groups in communities of dung beetles in Atlantic forest fragments adjacent to transgenic maize crops. Ecological Indicators, 49, 216-227.

Carrière Y, Crowder DW, Tabashnik BE (2010) Evolutionary ecology of insect adaptation to Bt crops. Evolutionary Applications, 3, 561-573.

Catangui MA, Berg RK (2006) Western bean cutworm, Striacosta albicosta (Smith) (Lepidoptera: Noctuidae), as a potential pest of transgenic Cry1Ab Bacillus thuringiensis corn hybrids in South Dakota. Environmental Entomology, 35, 1439-1452.

Catarino R, Ceddia G, Areal FJ, Park J (2015) The impact of secondary pests on Bacillus thuringiensis (Bt) crops. Plant Biotechnology Journal, 13, 601-612.

Chen M, Ye G, Liu Z, Fang Q, Hu C, Peng YF, Shelton AM (2009) Analysis of Cry1Ab toxin bioaccumulation in a food chain of Bt rice, an herbivore and a predator. Ecotoxicology, 18, 230-238.

Dorhout DL, Rice ME (2010) Intraguild competition and enhanced survival of western bean cutworm (Lepidoptera: Noctuidae) on transgenic Cry1Ab (MON810) Bacillus thuringiensis corn. Journal of Economic Entomology, 103, 54-62.

Dowd-Uribe B (2014) Engineering yields and inequality? How institutions and agro-ecology shape Bt cotton outcomes in Burkina Faso. Geoforum, 53, 161-171.

EFSA (2010) EFSA Panel on genetically modified organisms (GMO): Scientific opinion on the assessment of potential impacts of genetically modified plants on non-target organisms. EFSA Journal, 8, 73.

Eizaguirre M, Madeira F, López C (2010) Effects of Bt maize on non-target Lepidopteran pests. IOBC/WPRS Betin, 52, 49-55.

Fu Q, Lai FX, Chen Y, Li KL (2013) A review of the ecological 
safety of the insect-resistant transgenic rices to non-target organisms. Plant Physiology Journal, 49, 655-663. (in Chinese) [傅强, 赖凤香, 陈洋, 李凯龙 (2013) 抗虫转基因 水稻对非靶标生物的生态安全性研究进展. 植物生理学 报, 49, 655-663.]

Gassmann AJ, Carrière Y, Tabashnik BE (2009) Fitness costs of insect resistance to Bacillus thuringiensis. Annual Review of Entomology, 54, 147-163.

González-Cabrera J, García M, Hernández-Crespo P, Farinós GP, Ortego F, Castanera P (2013) Resistance to Bt maize in Mythimna unipuncta (Lepidoptera: Noctuidae) is mediated by alteration in Cry1Ab protein activation. Insect Biochemistry and Molecular Biology, 43, 635-643.

Gressel J, Gassmann AJ, Owen MD (2016) How well will stacked transgenic pest/herbicide resistances delay pests from evolving resistance? Pest Management Science, 73, 22.

Gross K, Rosenheim JA (2011) Quantifying secondary pest outbreaks in cotton and their monetary cost with causal-inference statistics. Ecological Applications, 21, 2770-2780.

Guan ZJ, Lu SB, Huo YL, Guan ZP, Liu B, Wei W (2016) Do genetically modified plants affect adversely on soil microbial communities? Agriculture, Ecosystems and Environment, 235, 289-305.

Guedes RNC, Cutler GC (2014) Insecticide-induced hormesis and arthropod pest management. Pest Management Science, 70, 690-697.

Hagenbucher S, Wackers FL, Wettstein FE, Olson DM, Ruberson JR, Romeis J (2013) Pest trade-offs in technology: Reduced damage by caterpillars in Bt cotton benefits aphids. Proceedings of the Royal Society B, 280, 1-8.

Han LZ, Bai SX, Zhao JZ, Wang ZY, Wu KM (2007) Progress in ecological biosafety of insect-resistant transgenic cotton and corn in relation to arthropods. Acta Entomologica Sinica, 50, 727-736. (in Chinese with English abstract) [韩 兰芝, 白树雄, 赵建周, 王振营, 吴孔明 (2007) 转基因 抗虫棉花和玉米与节肢动物相关的生态安全性研究进展. 昆虫学报, 50, 727-736.]

Han P, Niu CY, Desneux N (2013) Identification of top-down forces regulating cotton aphid population growth in transgenic Bt cotton in central China. PLoS ONE, 9, e102980.

Hardke JT, Leonard BR, Huang F, Jackson RE (2011) Damage and survivorship of fall armyworm (Lepidoptera: Noctuidae) on transgenic field corn expressing Bacillus thuringiensis Cry proteins. Crop Protection, 30, 168-172.

Huang J, Rozelle S, Pray C, Wang Q (2002) Plant biotechnology in China. Science, 295, 674-676.

Hutchison WD, Burkness EC, Mitchell PD (2010) Areawide suppression of European corn borer with Bt maize reaps savings to non-Bt maize growers. Science, 330, 222-225.

Hutchison WD, Hunt TE, Hein GL (2011) Genetically engineered $B t$ corn and range expansion of the western bean cutworm (Lepidoptera: Noctuidae) in the United States: A response to Greenpeace Germany. Journal of Integrated Pest
Management, 2, B1-B8.

ISAAA (2016) Global Status of Commercialized Biotech/GM Crops: 2016. ISAAA Brief No. 52. ISAAA: Ithaca, NY.

Kilic A, Akay MT (2008) A three generation study with genetically modified $B t$ corn in rats: Biochemical and histopathological investigation. Food \& Chemical Toxicology, 46, 1164-1170.

Krishna VV, Qaim M (2012) Bt cotton and sustainability of pesticide reductions in India. Agricultural Systems, 107, 47-55.

Kruger M, Van Rensburg JBJ, Van den Berg J (2012) Transgenic Bt maize: Farmers' perceptions, refuge compliance and reports of stem borer resistance in South Africa. Journal of Applied Entomology, 136, 38-50.

Kumar R, Tian JC, Naranjo SE, Shelton AM (2014) Effects of Bt cotton on Thrips tabaci (Thysanoptera: Thripidae) and its predator, Orius insidiosus (Hemiptera: Anthocoridae). Journal of Economic Entomology, 107, 927.

Ladics GS, Bartholomaeus A, Bregitzer P, Doerrer NG, Gray A, Holzhauser T, Jordan M, Keese P, Kok E, Macdonald P, Parrott W, Privalle L, Raybould A, Rhee SY, Rice E, Romeis J, Vaughn J, Wal JM, Glenn K (2015) Genetic basis and detection of unintended effects in genetically modified crop plants. Transgenic Research, 24, 587-603.

Lin ZF, Chen HY, Ji XC (2015) Insect resistance to Bt crops: Possible mechanism and resistance management strategy. Journal of Tropical Biology, 6, 497-503. (in Chinese with English abstract) [林珠风, 陈海燕, 吉训聪 (2015) 害虫 对转 $B t$ 基因作物的抗性及治理. 热带生物学报, 6 , 497-503.]

Lindroth E, Hunt TE, Skoda SR, Culy MD, Lee D, Foster JE (2012) Population genetics of the western bean cutworm (Lepidoptera: Noctuidae) across the United States. Annals of the Entomological Society of America, 105, 685-692.

Liu B (2016) Research progresses on the environmental safety of transgenic Bt plants with insect-resistant trait. Journal of Nanjing Normal University (Natural Science Edition), 39, 1025-1030. (in Chinese with English abstract) [刘标 (2016) 抗虫转 $B t$ 基因植物的环境安全研究进展. 南京师大学报 (自然科学版), 39, 1025-1030.]

Lövei GL, Andow DA, Arpaia S (2009) Transgenic insecticidal crops and natural enemies: A detailed review of laboratory studies. Environmental Entomology, 38, 293-306.

Lu Y, Wu K, Jiang Y, Guo Y, Desneux N (2012) Widespread adoption of Bt cotton and insecticide decrease promotes biocontrol services. Nature, 487, 362-365.

Lu Y, Wu K, Jiang Y, Xia B, Li P, Feng H, Wyckhuys KA, Guo Y (2010) Mirid bug outbreaks in multiple crops correlated with wide-scale adoption of Bt cotton in China. Science, 328, 1151-1154.

Lu YH (2012) Advance in insect pest management in Bt cotton worldwide Chinese. Chinese Journal of Applied Entomology, 49, 809-819. (in Chinese with English abstract) [陆宴 
辉 (2012) Bt棉花害虫综合治理研究前沿. 应用昆虫学报, 49, 809-819.]

Lu YH, Liang GM (2016) Research advance on the succession of insect pest complex in Bt crop ecosystem. Plant Protection, 42, 7-11. (in Chinese with English abstract) [陆宴辉, 梁革梅 (2016) Bt作物系统害虫发生演替研究进展. 植物 保护, 42, 7-11.]

Lu YH, Qiu F, Feng HQ, Li HB, Yang ZC, Wyckhuys KAG, Wu KM (2008) Species composition and seasonal abundance of pestiferous plant bugs (Hemiptera: Miridae) on $\mathrm{Bt}$ cotton in China. Crop Protection, 27, 465-472.

Luttrell RG, Teague TG, Brewer MJ (2015) Cotton insect pest management. In: Cotton, 2nd edn (eds David DF, Richard GP). Agronomy Monograph 57. pp. 509-546. ASA, CSSA, and SSSA, Madison, WI.

Ma H, Xia XM, Zhou Y, Zhao M, Wang HY (2009) Impact of transgenic Bt cotton on non-target insects. Chinese Agricultural Science Bulletin, 25, 214-218. (in Chinese with English abstract) [马惠, 夏晓明, 周玉, 赵鸣, 王红艳 (2009) 转Bt基因抗虫棉对非靶标昆虫的影响. 中国农学通报, 25, 214-218.]

Marvier M, McCreedy C, Regetz J, Kareiva P (2007) A meta-analysis of effects of Bt cotton and maize on nontarget invertebrates. Science, 316, 1475-1477.

Mccoll SA, Khan M, Umina PA (2011) Review of the biology and control of Creontiades dilutus (Stål) (Hemiptera: Miridae). Austral Entomology, 50, 107-117.

Meissle M, Mouron P, Musa T, Bigler F, Pons X (2010) Pests, pesticide use and alternative options in European maize production: Current status and future prospects. Journal of Applied Entomology, 134, 357-375.

Naranjo SE (2005) Long-term assessment of the effects of transgenic Bt cotton on the abundance of non-target arthropod natural enemies. Environmental Entomology, 34, 1193-1210.

Naranjo SE (2009) Impacts of Bt crops on non-target invertebrates and insecticide use patterns. CAB Reviews, 4(11), $1-23$.

Naranjo SE (2010) Impacts of Bt transgenic cotton on integrated pest management. Journal of Agricultural and Food Chemistry, 59, 5842-5851.

Naranjo SE (2014) Effects of GM crops on non-target organisms. In: Plant Biotechnology (ed Naranjo SE), pp. 129-142, Springer International Publishing, New York.

Naranjo SE, Ellsworth PC (2009) The contribution of conservation biological control to integrated control of Bemisia tabaci in cotton. Biological Control, 51, 458-470.

Naranjo SE, Ruberson JR, Sharma HC, Wilson L, Wu KM (2008) The present and future role of insect-resistant GM cotton in IPM. In: Integration of Insect-Resistant Genetically Modified Crops Within IPM Programs (eds Romeis J, Shelton AM, Kennedy GG), pp. 159-194. Springer International Publishing, New York.
National Academies of Sciences, Engineering, and Medicine (2016) Genetically Engineered Crops: Experiences and Prospects. The National Academies Press, Washington, DC.

Pemsl DE, Voelker M, Wu L, Waibel H (2011) Long-term impact of Bt cotton: Findings from a case study in China using panel data. International Journal of Agricultural Sustainability, 9, 508-521.

Pérez-Hedo M, López C, Albajes R, Eizaguierre M (2012) Low susceptibility of non-target Lepidopteran maize pests to the Bt protein Cry1Ab. Bulletin of Entomological Research, 102, 737-743.

Razze JM, Mason CE (2012) Dispersal behavior of neonate European corn borer (Lepidoptera: Crambidae) on Bt corn. Journal of Economic Entomology, 105, 1214-1223.

Ricroch A, Chopra S, Fleischer S (2014) Plant Biotechnology: Experience and Future Prospects. Springer International Publishing, New York.

Shahid AA, Bano S, Khalid S, Samiullah TR, Bajwa KS, Ali MA (2016) Biosafety assessment of transgenic Bt cotton on model animals. Advancements in Life Sciences, 3(3), 97-108.

Shi G, Chavas JP, Lauer J (2013) Commercialized transgenic traits, maize productivity and yield risk. Nature Biotechnology, 31, 111-114.

Snow AA, Andow DA, Gepts P, Hallerman E, Power A, Tiedje J, Wolfenbarger L (2005) Genetically engineered organisms and the environment: Current status and recommendations. Ecological Applications, 15, 377-404.

Stephens EJ, Losey JE, Allee LL, DiTommaso A Bodner C, Breyre A (2012) The impact of Cry3Bb Bt-maize on two guilds of beneficial beetles. Agriculture, Ecosystems and Environment, 156, 72-81.

Tanwar RK, Jeyakumar P, Singh A, Jafri AA, Bambawale OM (2011) Survey for cotton mealybug, Phenacoccus solenopsis (Tinsley) and its natural enemies. Journal of Environmental Biology, 32, 381-384.

Tindall KV, Siebert MW, Leonard BR, All J, Haile FJ (2009) Efficacy of Cry1Ac: Cry1F proteins in cotton leaf tissue against fall armyworm, beet armyworm, and soybean looper (Lepidoptera: Noctuidae). Journal of Economic Entomology, 102, 1497-1505.

Virla EG, Casuso M, Frias EA (2010) A preliminary study on the effects of a transgenic corn event on the non-target pest Dalbulus maidis (Hemiptera: Cicadellidae). Crop Protection, 29, 635-638.

Wang YY, Li YH, Chen XP, Wu HJ, Peng YF (2011) Progress in the assessment of ecological effects of insect-resistant plants on non-target arthropods. Journal of Biosafety, 20, 100-107. (in Chinese with English abstract) [王园园, 李云 河, 陈秀萍, 武红巾, 彭于发 (2011) 抗虫转基因植物对 非靶标节肢动物生态影响的研究进展. 生物安全学报, 20, 100-107.]

Wei W, Guan ZJ, Ma KP (2016) Advances on ecological risk 
assessment of genetically modified crops. In: New Biology Yearbook 2015 (ed. the Editorial Board of New Biology Yearbook 2015), pp. 137-155. Science Press, Beijing. (in Chinese) [魏伟, 关正君, 马克平 (2016) 转基因作物的生 态风险评价研究进展. 见: 新生物学年鉴2015 (新生物学 年鉴2015编委会主编), 137-155页. 科学出版社, 北京.]

Wei W, Ma KP (2016) Transgenic organisms and biosafety. Bulletin of Chinese Academy of Sciences, 31, 405-413. (in Chinese with English abstract) [魏伟, 马克平 (2016) 转基 因与生物安全. 中国科学院院刊, 31, 405- 413.]

Wei W, Schuler TH, Clark SJ, Stewart CN, Poppy GM (2008) Movement of transgenic plant-expressed Bt Cry1Ac proteins through high trophic levels. Journal of Applied Entomology, 132, 1-11.

Wolfenbarger LLR, Naranjo SE, Lundgren JG, Bitzer RJ, Watrud LS (2008) Bt crop effects on functional guilds of non-target arthropods: A meta-analysis. PLoS ONE, 3, e2118.

Wu KM, Guo YY (2005) The evolution of cotton pest management practices in China. Annual Review of Entomology, 50, 31-52.

Xu N, Fok M, Bai L, Zhou L (2008) Effectiveness and chemical pest control of Bt-cotton in the Yangtze River Valley, China. Crop Protection, 27, 1269-1276.

Yan LZ, Zhao CY, Liu XY, Lv FC, Guan X, Liu MH, Li JS (2011) Influence and mechanism of transgenic Bt crops on the food chain: Plant-pest-predator. Plant Protection, 37(6), 27-31. (in Chinese with English abstract) [问亮珍, 赵彩云, 柳晓燕, 吕凤春, 关潇, 刘茂华, 李俊生 (2011) 转Bt基 因作物对植物-害虫-天敌食物链的影响. 植物保护, 37(6), 27-31.]

Yang H, Peng Y, Tian J, Wang J, Song Q, Wang Z (2017) Review: Biosafety assessment of Bt rice and other Bt crops using spiders as example for non-target arthropods in China. Plant Cell Reports, 36(4), 1-13.
Yang Y, Li YH, Cao FQ, Cheng LS, Peng YF (2014) Progress in the assessment of ecological effects of insect-resistant Bt crops on non-target of Lepidopteran insects. Journal of Biosafety, 23, 224-237. (in Chinese with English abstract) [杨 艳, 李云河, 曹凤勤, 程立生, 彭于发 (2014) 转Bt基因 抗虫作物对鳞翅目非靶标昆虫生态影响的研究进展. 生 物安全学报, 23, 224-237.]

Ye GY, Chen Y, Tian JC, Peng YF (2011) The effects of transgenic $B t$ insect-resistant crops on non-target organisms. Plant Protection, 37(6), 1-10. (in Chinese with English abstract) [叶恭银, 陈洋, 田俊策, 彭于发 (2011) 转Bt基因 抗虫作物对非靶标生物的影响. 植物保护, 37(6), 1-10.]

Yuan YY, Ge F (2010) Effects of transgenic Bt crops on non-target soil animals. Chinese Journal of Applied Ecology, 21, 1339-1345. (in Chinese with English abstract) [袁 一杨, 戈峰 (2010) 转Bt 基因作物对非靶标土壤动物的影 响. 应用生态学报, 21, 1339-1345.]

Zeilinger AR, Olson DM, Andow DA (2016) Competitive release and outbreaks of non-target pests associated with transgenic Bt cotton. Ecological Applications, 26, 1047-1054.

Zeng RS, Sun ZX, Song YY, Lu K, Zhu KY (2016) The mechanism of phytophagous insects accommodating protease inhibitors. In: New Biology Yearbook 2015 (ed. the Editorial Board of New biology Yearbook 2015). Science Press, Beijing. 117-137. (in Chinese) [曾任森, 孙仲享, 宋 圆圆, 卢凯, 朱克岩 (2016) 植食性昆虫适应植物蛋白酶 抑制剂的机制. 见: 新生物学年鉴2015 (新生物学年鉴 2015编委会主编), 117-137页. 科学出版社, 北京.]

Zhao JH, Ho P, Azadi H (2011) Benefits of Bt cotton counterbalanced by secondary pests? Perceptions of ecological change in China. Environmental Monitoring and Assessment, 173, 985-994.

(责任编委: 卢宝荣 责任编辑: 时意专) 